Int. J. Dev. Biol. 57: 483-494 (2013)

doi: $10.1387 / \mathrm{ijdb} .130232 \mathrm{mv}$

\title{
Higher plant transformation: principles and molecular tools
}

\author{
SYLVESTER ANAMI",1, ELIZABETH NJUGUNA ${ }^{\#, 2,3}$, GRIET COUSSENS 2,3 , \\ STIJN AESAERT ${ }^{2,3}$ and MIEKE VAN LIJSEBETTENS*,2,3 \\ ${ }^{1}$ Laboratory of Plant Genetics and Systems Biology, Department of Pure and Applied Sciences, Technical University \\ of Mombasa, Mombasa, Kenya, ${ }^{2}$ Department of Plant Systems Biology, VIB, Gent, Belgium and ${ }^{3}$ Department of Plant \\ Biotechnology and Bioinformatics, Ghent University, Gent, Belgium
}

\begin{abstract}
In higher plants, genetic transformation, which is part of the toolbox for the study of living organisms, had been reported only $\mathbf{3 0}$ years ago, boosting basic plant biology research, generating superior crops, and leading to the new discipline of plant biotechnology. Here, we review its principles and the corresponding molecular tools. In vitro regeneration, through somatic embryogenesis or organogenesis, is discussed because they are prerequisites for the subsequent Agrobacterium tumefaciens-mediated transferred (T)-DNA or direct DNA transfer methods to produce transgenic plants. Important molecular components of the T-DNA are examined, such as selectable marker genes that allow the selection of transformed cells in tissue cultures and are used to follow the gene of interest in the next generations, and reporter genes that have been developed to visualize promoter activities, protein localizations, and protein-protein interactions. Genes of interest are assembled with promoters and termination signals in Escherichia coli by means of GATEWAY-derived binary vectors that represent the current versatile cloning tools. Finally, future promising developments in transgene technology are considered.
\end{abstract}

KEYWORDS: Agrobacterium tumefaciens, T-DNA, transgene, plant transformation, somatic embryogenesis, organogenesis

\section{Shoot regeneration in tissue culture}

Genetic transformation usually involves DNA delivery to explants and subsequent tissue culture in which transformed cells are selected and induced either to form transgenic callus, shoots, roots, or somatic embryos. Hence, the tissue culture-induced regeneration capacity of a plant genotype is crucial for a successful genetic transformation. Indeed, recalcitrance to in vitro regeneration prevents genetic transformation in a large number of plant species or varieties. In vitro shoot regeneration competence has a genetic basis because it can be introgressed from a highly regenerative into a recalcitrant genotype (Koornneef et al., 1993; Anami et al., 2010). Therefore, identification of genes promoting or inhibiting the tissue culture-induced regeneration capacity will help to broaden the range of plant species for genetic transformation. Tissue culture regeneration occurs through organogenesis or somatic embryogenesis, which are discussed below and are schematically presented in Fig. 1.

\section{Somatic embryogenesis}

Somatic embryos develop from undifferentiated somatic cells in cultures and are morphologically and developmentally very similar to zygotic embryos, which are formed upon fertilization and surrounded by maternal tissue. Somatic embryogenesis was first demonstrated in embryogenic carrot (Daucus carota) liquid cultures that differentiated into somatic embryos at high frequency when diluted, sieved for the embryogenic subpopulation, and transferred to a medium lacking the synthetic hormone 2,4-dichloro-phenoxyacetic acid (2,4-D) (Steward et al., 1958) (Fig. 1A). This embryogenic suspension culture system has been used as a model to study the regulatory genetic program of plant zygotic embryogenesis (Zimmerman, 1993). Indeed, all stages of the embryo formation, such as globular, heart, and torpedo, can be distinguished in the

Abbreviations used in this paper: GFP, green fluorescent protein; GUS, $\beta$-glucuronidase; T-DNA, transferred DNA; 2,4-D, 2,4-dichloro-phenoxyacetic acid; TALEN, transcription activator-like effector nuclease; vir, virulence; ZFN, zinc finger nuclease.

\footnotetext{
*Address correspondence to: Mieke Van Lijsebettens, VIB-Ghent University, Technologiepark 927, B-9052 Gent, Belgium. Tel.: +32 93313970 . Fax: +32 93313809. E-mail: milij@psb.ugent.be
}

\#Note:These authors contributed equally to this work.

Final, author-corrected PDF published online: 25 September 2013.

ISSN: Online 1696-3547, Print 0214-6282

(C) 2013 UBC Press

Printed in Spain 


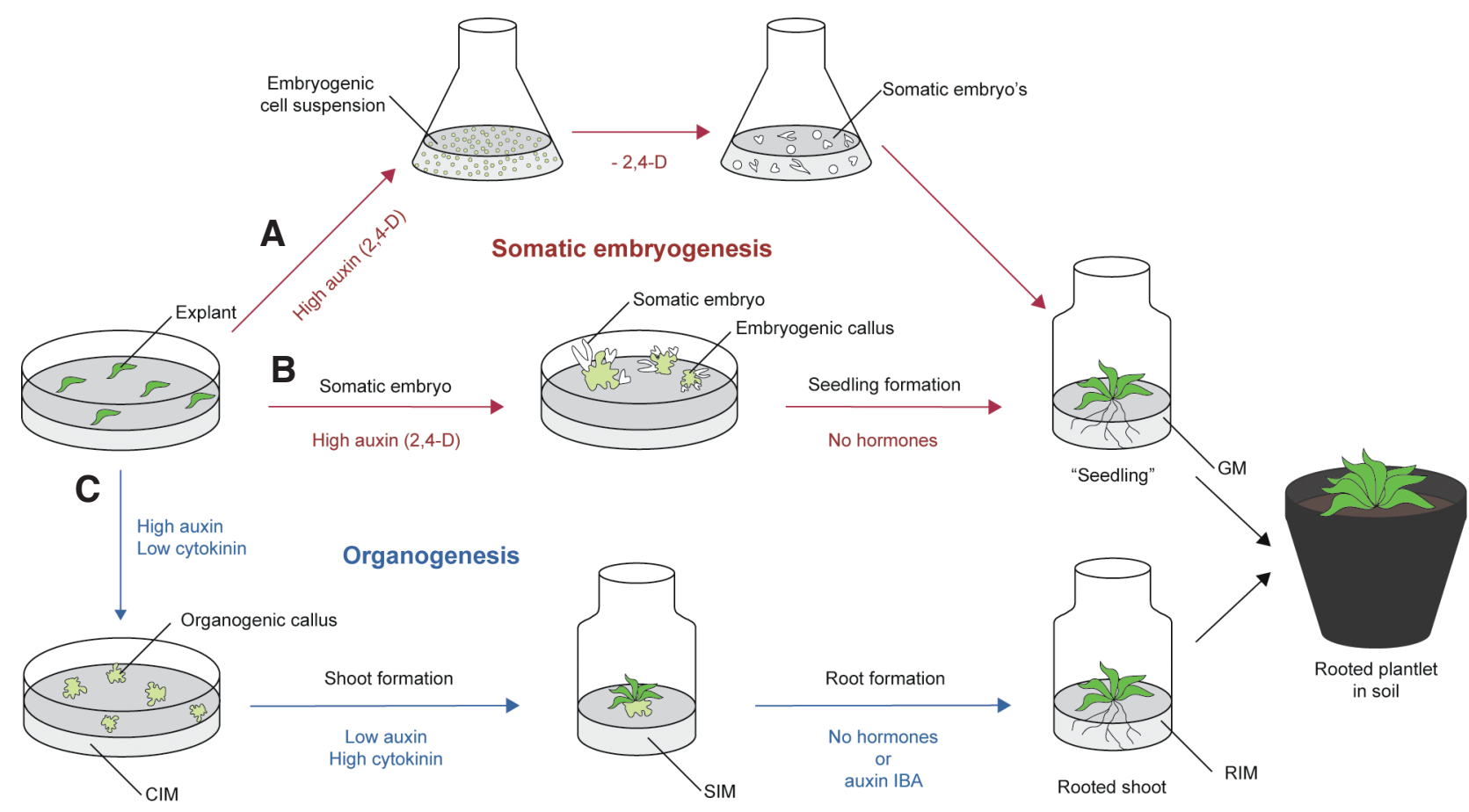

Fig. 1. Somatic embryogenesis versus shoot regeneration. (A) Somatic embryogenesis through embryogenic cell suspension cultures. (B) Somatic embryogenesis through embryogenic callus cultures. (C) Shoot regeneration through organogenesis.

embryogenic cultures and, upon removal of the exogenous auxin, the induction of the gene expression programs is comparable to that of the zygotic embryogenesis (Borkird et al., 1986). The somatic embryogenesis receptor-like kinase SERK1 marks somatic plant cells that are competent to form somatic embryos in the carrot cultures (Schmidt et al., 1997). Endogenous abscisic acid signaling is essential for carrot cells to acquire the embryogenic competence and for zygotic embryogenesis (Parcy et al., 1994; Kikuchi et al., 2006). Transcription factors expressed during embryogenesis, such as the ABSCISICACID-INSENSITIVE3/LEAFY COTYLEDON1/FUSCA3, are specific markers for embryogenesis that play a crucial role in the embryogenic process as demonstrated by knockout or overexpression lines (Lotan et al., 1998).

Today, many plant species of agronomic and horticultural importance are regenerated in tissue cultures through somatic embryogenesis, among which the cereals (Shrawat and Lörz, 2006). Somatic embryogenesis in crop plants requires high concentrations of auxin, 2,4-D or dicamba to promote the vegetativeto-embryogenic transition in a small subset of cultured cells that are then committed to form somatic embryos. The somatic embryo is a bipolar structure with shoot apical meristem and radicle in contrast to the monopolar shoot structure originating through organogenesis. The embryo originates from a single cell and has no vascular connection with the maternal callus tissue or the cultured explant. Hence, somatic embryos are clonal unlike shoots regenerated by organogenesis that usually arise from several individual cells and might be chimearic, i.e. consisting of a mixture of independently transformed cells. Furthermore, induction of somatic embryogenesis requires a single hormonal signal to trigger a bipolar structure capable of forming a complete plant consisting of root and shoot and resembling a "seedling" (Fig. 1B). In organogenesis, shoots induced from organogenic callus are removed from the callus to form roots on hormone-free or "rooting" medium (Fig. 1C).

\section{Organogenesis}

According to the "classical theory", in vitroorganogenesis refers to organ formation of de novo origin, involving phytohormone perception, dedifferentiation of differentiated cells into callus, acquisition of organogenic competence, re-entry of quiescent cells into the cell cycle, and organization of cell division to form specific organ primordia and meristems (Sugiyama. 1999). The pioneering work of Skoog and Miller (1957) and Christianson and Warnick (1983) established that auxin and cytokinin are the predominant growth regulators of tissue culture organogenesis. Shoot regeneration in tissue cultures usually needs a two-step hormone treatment (Fig. 1C). A high auxin/cytokinin ratio in the medium induces organogenic callus from an explant and, subsequently, a high cytokinin/auxin ratio triggers shoot formation. Such shoots originate typically from monopolar and callus-derived organ primordia, develop into shoots with leaves, and form roots upon transfer to medium without hormones or containing the "rooting" auxin isobutyric acid. Organogenic callus cultures with subsequent shoot organogenesis have been established in many species by means of numerous types of explants, including tobacco (Nicotiana tabacum L.) protoplasts (Nagy and Maliga, 1976), Arabidopsis thaliana root explants (Valvekens et al., 1988) and leaf explants. A number of gene regulatory circuits important for dedifferentiation, redifferentiation, and adventitious meristem organization during in vitro regeneration of plants have been identified of which their components might be exploited as new tools to improve the plant regeneration efficiency (Duclercq et al., 2011). Organogenic callus induction on auxin-containing medium corresponds with the competence (cell dedifferentiation) acquired by tissues to respond to hormonal signals and to upregu- 
late AUXIN/INDOLE-3-ACETIC ACID genes. Shoot induction on cytokinin-containing medium coincides with the upregulation of the shoot apical meristem genes WUSCHEL (WUS) and CLAVATA3 (CLV3) (Che et al., 2006; Bao et al., 2009), that might be applied in the future to enhance in vitro propagation as demonstrated by the overexpression of the SHOOTMERISTEMLESS (STM) and ZWILLE2 (ZLL2) genes in Brassica napus (canola) and Arabidopsis plants (Elhiti and Stasolla, 2012; Chatfield et al., 2013).

In tomato (Solanum lycopersicum) and Brassica rapa (turnip), in which organogenic callus induction and plant regeneration are quantitatively controlled by several genes (Trujillo-Moya and Gisbert, 2012; Seo et al., 2013), candidate genes in the genetic quantitative trait locus (QTL) intervals were APETALA2 (AP2)-containing ethylene response factors (ERFs), homologous to the well characterized Arabidopsis gene ENHANCEROF SHOOTREGENERATION1 (ESR1) (Banno etal., 2001), MADS box genes related to adventitious shoot regeneration (Prakash and Kumar, 2002), and serine-threonine kinases of which the tomato shoot kinase 1 LESK1 is an in vitro organogenesis competence marker (Torelli et al., 2004).

Recent literature on shoot regeneration in Arabidopsis shows the need to revisit the concept of cell dedifferentiation upon organogenic callus formation (Sugimoto et al., 2011). Shoots originate from organogenic callus derived from specific pericycle-like cells surrounding the vasculature in roots, hypocotyls, or cotyledon explants (Che et al., 2007; Atta et al., 2009). The transcript profile of organogenic callus is strikingly similar to that of lateral roots (Che et al., 2006), indicating that shoot regeneration occurs via a "root developmental pathway" (Sugimoto et al., 2010). As pericycle cells are the progenitors of lateral roots in primary roots, they might be considered as "adult meristem cells" that differentiate into organogenic callus from which shoots develop upon hormonal stimuli in tissue cultures (Sugimoto et al., 2011).

Inherent to tissue culture procedures is the socalled somaclonal variation that refersto mutations, chromosome rearrangements and multiplication in some of the regenerated shoots, hinting at induction of stress reactions and accumulation of genetic aberrations during the dedifferentiation/ redifferentiation processes (Jiang et al., 2011). In order to restrict somaclonal variation, tissue culture duration should be kept as short as possible, tissue culture-related "stress" should be reduced by addition of antioxidantia and organic buffer to the medium, a low light intensity, and minimal concentrations of selectable agents and hormones.

\section{Techniques for higher plant transforma- tion}

The role of transgenes in higher plants can be studied through both transient and stable transformation methods. Stable transformants are generated by means of Agrobacterium infection or particle bombardment and contain a stably integrated transgene in their plant genome that segregates as a Mendelian trait and is inherited in subsequent generations (Fig. 2). In contrast, transient transformants are obtained by biolistic treatment or agroinfection of explants, such as onion (Allium cepa) epidermis or protoplats by which gene construct expression, subcellular localization, or protein targeting can be

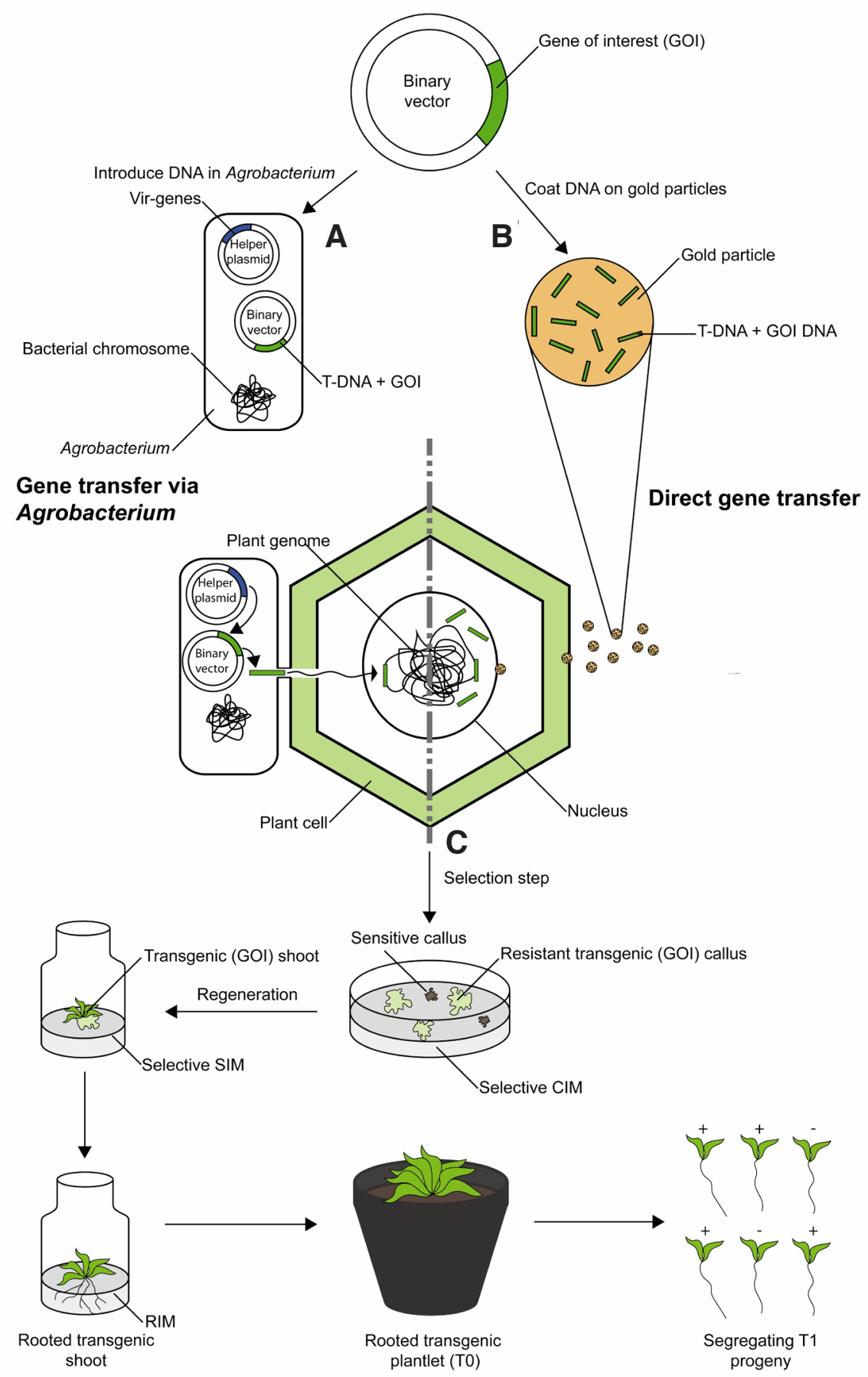

Fig. 2. Techniques for genetic transformation. (A) Agrobacterium-mediated T-DNA transfer. (B) Direct DNA transfer through particle bombardment or biolistics. (C) Regeneration and selection of transformed callus and shoots. 
tested without integration of the transgene into the genome, thus circumventing in vitro shoot regeneration procedures (Sheen, 2001). Agroinfiltration of Nicotiana benthamiana leaves is the preferred method to investigate in-vivo protein-protein interactions by means of fluorescence resonance energy transfer and bimolecular fluorescence complementation technology in which proteins are fused with a fluorescent protein and their interaction is visualized by confocal microscopy (Yang et al., 2000; Boruc et al., 2010). Recently, transient transformation assays have been developed in cereals, such as rice (Oryza sativa) and maize (Zea mays). A high fluorescent marker gene expression has been demonstrated in bombarded leaf explants of maize that consisted of the basal-most $3 \mathrm{~cm}$ above the ligule of an approximately $50-\mathrm{cm}$ growing adult leaf using different fluorescent protein tags and correct localization to the endoplasmic reticulum, the Golgi apparatus, and the plasma membrane was demonstrated (Kirienko et al., 2012).

In stable transformants, transgenes are studied at the genetic, morphological, physiological, cell biological, and biochemical levels to gain insight into their function and might be the basis for translational or biotechnological research. Below, Agrobacteriummediated transformation and direct gene transfer are discussed.

\section{Agrobacterium-mediated transformation}

Agrobacterium tumefaciens-mediated transformation exploits the bacterium as the biological vehicle to transfergene(s) of interest into the plant cell and involves a number of proteins derived from both the plant host and the bacterial pathogen (Gelvin, 2012). Naturally, the bacterium induces crown gall tumors on various plant species, including many agronomically important crops. During its infection, Agrobacterium replicates a single-stranded copy of the bacterial transferred (T)-DNA that is located on the tumor-inducing ( $\mathrm{Ti}$ ) plasmid and transfers it into the plant host cell where it subsequently integrates into the host genome. The wildtype T-DNA encodes several genes involved in auxin and cytokinin biosynthesis that are expressed in the infected plant cells, with cell proliferation and tumor formation as a consequence. With the help of other T-DNA-encoded genes, the tumors synthesize and secrete opines, amino acid derivatives that can be metabolized mainly by Agrobacterium. This unique infection strategy allows Agrobacterium to hijack the host cell machinery and turn it into its own "food factory". Although Agrobacterium mainly infects dicotyledonous plants in nature (De Cleene and De Ley, 1976), it can genetically transform a wide range of higher plant species under laboratory conditions and has become the transformation vehicle of choice for the genetic manipulation of most plant species (Tzfira and Citovsky, 2006).

The T-DNA was adapted for genetic engineering by removing the hormone and opine biosynthesis genes and by replacing them with a selectable marker gene and one or more genes of interest, flanked by the T-DNA left and right border sequences that delineate the T-DNA. The T-DNAs are engineered in Escherichia coli on a binary vector that is introduced into an Agrobacterium strain containing a T-DNA-less, so-called "helper", Ti plasmid harboring the virulence (vir ) functions that are required for the bacterium-host recognition, the T-DNA replication in the bacterium, and the T-DNA transfer to and integration into the plant genome (Fig. 2A). Agrobacteria containing the engineered vectors are usually co-cultivated with specific explants from which transgenic shoots or somatic embryos are regenerated and selected in tissue cultures (Fig. 2C). In Arabidopsis, floral buds can be submerged in a liquid Agrobacterium culture and transgenic plants can be selected from the seeds (Clough and Bent, 1998), a method that avoids tissue culture procedures.

Upon Agrobacterium-mediated transformation, usually intact, single, or tandemly arranged T-DNA copies in one or two loci are stably integrated into AT-rich regions of the nuclear plant genome with minimal rearrangement of the target site (Gheysen et al., 1991). At low frequency, T-DNAs are truncated at their left border and vector backbone DNA is integrated (Tzfira and Citovsky, 2006). The selectable marker and the gene of interest, located on the T-DNA, are inherited in subsequent generations and segregate according to Mendelian genetics (De Block et al., 1984; Horsch et al., 1984). Agrobacterium-mediated transformation is the method of choice for overexpression or down-regulation of genes of interest in functional basic research or for generation and commercialization of superior crops thanks to its rather precise replication through the T-DNA border sequences upon infection and the low-copy T-DNA insertion into the genome. The T-DNA has been used as mutagen itself or to introduce transposons for mutagenization into several plant species, resulting in mutagenized collections that are invaluable resources for gene identification and functional analysis (Alonso et al., 2003).

\section{Direct gene transfer}

In nature, the host range of plant species and genotypes that are competent for Agrobacterium infection is limited, indeed, competence is determined by bacterial and plant host genes the study of which might help to enlarge the natural Agrobacterium host range. To overcome competence barriers, "direct" gene transfer methods have been developed in which genes of interest are delivered directly into regenerable plant tissues. Gene transfer by high-velocity microprojectiles (biolistic or particle bombardment) is widely used and has expanded the range of species and genotypes for genetic engineering (O'Kennedy et al., 2011) (Fig. 2B). Metal particles coated with naked plasmid DNA containing the gene of interest are transported to the plant cells by means of an electric discharge or in a pressurized helium stream. Nearly all of the physical and chemical parameters (rupture pressure, DNA concentration, particle travel distances, and vacuum degree) can be adjusted to different tissues and species. One of the first successes was the transfer of foreign genes into intact maize cells of a Black Mexican Sweet cultivar suspension culture (Klein et al., 1988). Particle bombardment is frequently used for the transformation of cereals with immature embryos as explants (Shrawat and Lörz, 2006) and is the only effective method to transform chloroplasts in plants.

However high-copy numbers and extensive rearrangements of the foreign DNA have frequently been reported in plants stably transformed with direct gene transfer methods. The integration of too many copies of the same gene within the genome normally results in gene silencing. In addition, sequences of the introduced gene have been found to be truncated, making the transgene analysis difficult and undesirable. Only DNA fragments of less than $10 \mathrm{~kb}$ in size can be transferred by the biolistic technology because large fragments get destroyed during the bombardment or adhere poorly to the metal particle, with messy DNA integration events as a consequence (Shou et al., 2004). 


\section{Selectable marker genes}

Selectable marker genes are used to identify cells that have incorporated the T-DNA with the marker gene and the gene of interest upon genetic transformation of explants as well as to monitor the transformed individuals in subsequent generations. Upon infection or biolistic treatment of an explant, only a very small proportion of the cells is transformed; thus, the probability of recovering transformed lines without a selection system is very low. The most frequently used selectable markers include antibiotic resistance genes, such as neomycin and hygromycin phosphotransferases, herbicide resistance genes, such as phosphinothricin $\mathrm{N}$-acetyltransferase and aceto lactate synthase, and metabolism-related genes, such as phosphomannose isomerase. These marker genes have been adopted for widespread use because of their efficiency and general applicability to a wide range of species and tissue culture systems (Table 1). Additional selectable metabolism-related markers, such as xylose isomerase, trehalose-6P-synthase, and protoporphyrinogen oxidase, are less frequently used (Miki and McHugh, 2004). To function in a variety of cell types, selectable marker genes are constructed as chimeric genes, including regulatory sequences that ensure constitutive expression throughout the plant (Miki and McHugh, 2004).

\section{Neomycin phosphotransferase II gene}

Neomycin phospotransferase II (NPTII), also known as bacterial amino-glycoside 3'-phosphotransferease II (APH [3']), is an enzyme encoded by the npt/l or neo gene that had been isolated from the E. coli transposon Tn5. It confers resistance to its host cells against a wide range of amino-glycoside antibiotics, including kanamycin, neomycin, geneticin (G418), and paramomycin, by catalyzing the phosphorylation of the 3'-hydroxyl group of the amino-hexose portion of these aminoglycosides. In this manner, NPTII detoxifies the antibiotic, allowing transformed npt/l-expressing plants to tolerate certain concentrations of the aminoglycosidic antibiotics, unlike the nontransformed plants that undergo bleaching and growth inhibition at similar concentrations. The nptll gene has been used as a selection marker for vectors in prokaryotic and eukaryotic cells. It is the most widely used selectable marker system for generating transgenic plants, especially in dicotyledonous plants, such as Arabidopsis(Miki and McHugh, 2004). For constitutive expression in plants, the coding region of the npt/lgene has been fused to the 5'- and 3'-regulatory sequences of the Agrobacterium T-DNA gene nopaline synthase (nos). This gene construct has been shown to be efficient in selection of tobacco cells on kanamycin or G418 (Herrera-Estrella et al., 1983). Transformants sensitive and resistant to kanamycin and their progenies can be distinguished through different techniques, including seed germination assays on kanamycin-containing medium carried out to follow the nptll gene segregation in the progeny of primary transformants (De Block et al., 1984) and callus induction tests (Van Lijsebettens et al., 1991). Enzymatic in vitro assays that can detect the NPTII protein quantitatively or semiquantitatively are based on the transfer of the ${ }^{32} \mathrm{P}$-labeled $\gamma$-phosphate group from ATP to kanamycin (Reiss et al., 1984), whereas an enzyme-linked immunoabsorbent assay has been developed as well (Nagel et al., 1992).

\section{Hygromycin phosphotransferase gene}

The hygromycin phosphotransferase $(h p t)$ gene, also designated aphIV, was isolated from E. coli and encodes the enzyme hygromycin $B$ phosphotransferase that confers resistance to the antibiotic hygromycin B (Waldron et al., 1985), an aminocyclitol antibiotic that inhibits protein synthesis with a broad spectrum activity against prokaryotes and eukaryotes. The hpt gene has been modified for expression in plant cells by developing a chimeric gene consisting of the nos regulatory elements and the $E$. coli-derived hpt gene (van den Elzen et al., 1985). Hygromycin is more toxic in plants than kanamycin; hence, the $h p t$ selectable marker is used when npt/lis not effective. Hygromycin resistance in transformed plants can be checked in several ways, including callus induction tests (Van Lijsebettens et al., 1991), seed germination assays to score the segregation of the hpt gene in the transgenic plant progenies, and enzymatic assays (Datta et al., 1990).

\section{Bialaphos-resistant and phosphinothricin N-acetyltransfer- ase genes}

The bialaphos-resistant (bar) gene, isolated from Streptomyces hygroscopicus (Murakami et al., 1986) and the patgene, isolated from Streptomyces viridiochromogenes (Wohlleben et al., 1988), are $87 \%$ homologous and code for the enzyme phosphinothricin $\mathrm{N}$-acetyltransferase (PAT) that catalyzes the conversion of phosphinothricin (PPT) into a nontoxic acetylated form (Thompson et al., 1987). PPT, also designated glufosinate ammonium, is an active ingredient of several broad-spectrum herbicide formula-

TABLE 1

\section{FREQUENTLY USED SELECTABLE MARKER AND REPORTER GENES IN PLANT TRANSGENIC RESEARCH}

\begin{tabular}{|c|c|c|c|c|}
\hline Gene & Substrate - Enzyme & Origin & Effect & Reference \\
\hline NPT II & $\begin{array}{l}\text { Neomycin, kanamycin, geneticin (G418) - paramomycin } \\
\text { neomycin phosphotransferases II }\end{array}$ & Escherichia coli & $\begin{array}{l}\text { Inactivates a number of aminoglycoside } \\
\text { antibiotics by phosphorylation }\end{array}$ & Fraley et al. (1983) \\
\hline HPT & Hygromycin - hygromycin phosphotransferase & Escherichia coli & Inhibitor of protein synthesis & Waldron et al. (1985) \\
\hline$B A R, P A T$ & $\begin{array}{l}\text { Phosphinothricin (PPT) - phosphinothricin } \\
\text { acetyltransferase }\end{array}$ & $\begin{array}{l}\text { Streptomyces hygroscopicus, Streptomyces } \\
\text { viridochromogenes }\end{array}$ & $\begin{array}{l}\text { Acetylation of PPT a competitive inhibitor } \\
\text { of glutamine synthetase }\end{array}$ & $\begin{array}{l}\text { De Block et al. (1989), } \\
\text { Wohlleben et al. (1988) }\end{array}$ \\
\hline ALS & $\begin{array}{l}\text { Sulfonylureas and imidazolinones - acetolactate } \\
\text { synthase }\end{array}$ & $\begin{array}{l}\text { Mutated form: Arabidopsis thaliana, Oryza sativa, } \\
\text { Zea mays, Malus domestica }\end{array}$ & $\begin{array}{l}\text { Mutant ALS enzymes insensitive to } \\
\text { herbicides }\end{array}$ & Olszewski et al. (1988) \\
\hline $\operatorname{man} A$ & D-mannose - phosphomannose isomerase & Escherichia coli & Mannose used as carbon source & Joersbo et al. (1998) \\
\hline EGFP & None - enhanced green fluorescent protein & Victoria aequorea (modified from GFP) & Fluorescence & Yang et al. (1996) \\
\hline GUS & $\beta$-glucuronides $-\beta$-glucuronidase & Escherichia coli & Hydrolyzation of $\beta$-glucuronides & Jefferson et al. (1987) \\
\hline LUC & Luciferin - luciferase & Photinus pyralis & Oxidative decarboxylation of luciferin & Ow et al. (1986) \\
\hline$R \& C l$ & None $-\mathrm{R}$ and $\mathrm{Cl}$ anthocyanin transcriptional regulators & Zea mays & Anthocyanin accumulation in cell vacuoles & $\begin{array}{l}\text { Ludwig et al. (1990), } \\
\text { Lloyd et al. (1992) }\end{array}$ \\
\hline
\end{tabular}


tions, such as Basta ${ }^{\mathrm{TM}}$, Ignite ${ }^{\mathrm{TM}}$, and Liberty ${ }^{\mathrm{TM}}$. It is an L-glutamic acid analog and a competitive inhibitor of glutamine synthetase, the only enzyme that can catalyze ammonium assimilation into glutamic acid in plants. Inhibition of glutamine synthetase results in the rapid accumulation of ammonia and, eventually, plant cell death. The PAT enzyme catalyzes the acetylation of the free amino group of PPT, making it unable to bind to and inactivate glutamine synthetase. To engineer herbicide resistance in plants, the bar gene was placed under the control of a 35S cauliflower mosaic virus (CaMV) promoter and transgenic tobacco plants were resistant to high doses of PPT and bialaphos (De Block et al., 1987). Today, it is frequently used as a selectable marker in cereals, such as maize, wheat (Triticum aestivum), rice, and barley (Hordeum vulgare) (Shrawat and Lörz, 2006). Several assays have been developed for the bar/pat marker gene activity in transgenic progenies, such as germination on PPT-containing medium, spraying plants, or painting leaves with the herbicide. Upon PPT treatment, ammonium accumulation in the medium can be determined with a colorimetric assay, specifically of nontransgenic seedlings that cannot assimilate ammonium due to glutamine synthase inhibition in contrast to transgenic seedlings that assimilate ammonium (De Block et al., 1995). PAT proteins can be detected simply and quickly with the PAT assay kit (AgraStrip $\AA$ LL Strip test kit; Romer Labs ${ }^{\circledR}$, Union, MO, USA) that is based on a double-antibody sandwich principle.

\section{Mutated acetolactate synthase genes}

Acetolatate synthase (ALS) is the first common enzyme in the biosynthetic pathway of the branched-chain amino acids isoleucine, leucine, and valine. The plant $A L S g e n e$ is a target for several classes of herbicides, including sulfonylurea, imidazolinone, and pyrimidinyl carboxyl. Naturally occurring mutations in ALS confer herbicide resistance to a number of plant species (Chang and Duggleby, 1998). Single or double amino acid substitutions can induce herbicide resistance and have been utilized as effective selectable markers in homologous or heterologous plant species. For instance, the Arabidopsis als mutant has been applied in the selection of transgenic tobacco plants growing in a sulfonylurea herbicide-containing culture (Olszewski et al., 1988). Different point mutations in the $A L S$ gene that alter conserved amino acids have been isolated in rice and used as selectable markers into rice, wheat, and soybean (Glycine max) (Rosellini, 2011). The als mutant very efficiently selected transgenic maize in embryogenic cultures (Fromm et al., 1990); similarly, the als mutants generated by site-specific mutagenesis were used successfully as selectable markers in tobacco and apple (Malus domestica) transformation (Yao et al., 2013). The use of mutant plant ALS genes as selectable markers for transgenic plants is gaining importance because they occur in all plants and, thus, are expected to be publicly acceptable, not prompting food safety concerns as in the case of bacteria-derived selection genes.

\section{Phosphomannose isomerase gene}

The phosphomannose isomerase gene $(p m i)$ gene isolated from $E$. coli (also designated manA gene) encodes the enzyme phosphomannose isomerase (PMI) that catalyzes the reversible interconversion of mannose-6-phosphate and fructose-6-phosphate. Mannose-6-phosphate is obtained from mannose through a hexokinase phosphorylation activity; unlike fructose-6-phosphate, most plants cannot use it as a natural carbon source. Transgenic PMI-producing plants have a metabolic advantage over the nontransformed plants, because they are able to utilize mannose as a carbon source by converting mannose-6-phosphate to fructose-6-phosphate and can survive on a mannose-containing medium as the only or major carbon source. In nontransformed plants, mannose-6-phosphate accumulation inhibits glycolysis and leads to an arrest in cell growth and development. Although $\mathrm{PMI}$ is widely distributed in nature and found across kingdoms, it is absent in many plants, with the exception of soybean and other leguminous plants (Goldsworthy and Street, 1965). The $\mathrm{PMI}$ selection system with the $E$. coli manA gene under the control of the $35 \mathrm{~S}$ promoter has been reported to be very efficient. Indeed, transformation frequencies in sugar beet (Beta vulgaris) increased 10-fold when compared to the kanamycin selection (Joersbo et al., 1998). Similarly, the E. coli manA gene under the control of the maize ubiquitin promoter was reported to perform well in dicotyledonous and monocotyledonous plants (Reed et al., 2001). PMI expression assays have been applied to identify transgenic events and to sort them through segregating populations, such as a modified chlorophenol red assay (Kramer et al., 1993), in which the medium changed from red to yellow in tissues that could not metabolize mannose, and a seedling germination assay, in which the germination of nontransgenic seedings was completely inhibited when mannose was introduced into the medium (Reed et al., 2001).

\section{Reporter genes}

Reporter genes, also called screenable or scorable markers, are genes that code for proteins that can be detected directly or catalyze specific reactions with easily detectable products. They are particularly useful for promoter activity analysis, protein localization, and/or interaction studies. An ideal genetic reporter system should be in situ detectable, sensitive, quantitative, rapid, reproducible, safe, and with low or without endogenous background activity. The $\beta$-glucuronidase (GUS), luciferase (LUC), enhanced green fluorescent protein (EGFP) and anthocyanin are the most commonly used reporter genes in plant research (Table 1).

\section{Green fluorescent protein}

The green fluorescent protein (GFP) is a photoprotein cloned from the jelly fish Aequorea victoria (Shimomura et al., 1962; Prasher et al., 1992). It is a very stable protein that autofluoresces in the presence of UV or blue light illumination and does not require an external substrate. Niedz et al. (1995) were the first to show that the wild-type Aequorea GFP could be visualized in plant cells as an in vivo reporter of plant gene expression. Although wild type GFP was used successfully in plant cell and tissue expression studies, it had some disadvantages, such as aberrant splicing in plants and formation of cytotoxic and nonfunctional aggregates. Effective expression in whole plants was achieved upon modification of the GFP-coding sequence (Haseloff et al., 1997) that improved fluorescence intensity and thermostability. GFP has a small molecular size, thus facilitating the construction of fusion proteins for subcellular protein localization or protein-protein interactions. GFP visualization is nondestructive and allows the direct imaging of gene products in living tissues in real time at the cellular level. GFP has an autofluorescence capacity and, 
therefore, does not require addition of cofactors or exogenous substrates to produce light; moreover, it is very stable to heat, extreme $\mathrm{pH}$, and chemical denaturants. Several GFP mutants have been developed through amino acid substitution, resulting in variants with altered excitation and emission spectra, such as variants with shifts to cyan, red, and yellow that are used for colocalization of specific proteins; for a detailed discussion, see Vo $\beta$ et al. (2013). EGFP is one of these GFP variants that is commonly utilized because of its increased fluorescence intensity (Yang et al., 1996).

\section{$\beta$-Glucuronidase}

$\beta$-Glucuronidase (GUS) is a bacterial enzyme encoded by the $E$. coli uidA (gusA) gene that occurs in microorganisms, vertebrates, and invertebrates, but not in most higher plants (Jefferson et al., 1987). It catalyzes the hydrolysis of a wide variety of $\beta$-glucuronides, such as the chromogenic histochemical 5-bromo-4-chloro-3-indolyl- $\beta$-D-glucuronide (X-gluc), a colorless compound that is converted by the $\beta$-glucuronidase enzyme to an insoluble indigo blue product. It is used for in situ histochemical localizations of the $\beta$-glucuronidase activity in cells and tissues. The fluorogenic assay, in which $\beta$-glucuronidase cleaves the 4-methyl-umbelliferyl glucuronide (MUG) substrate into a blue fluorescent compound, quantifies the promoter strength (Coussens et al., 2012). The GUS enzyme is very stable within plants and nontoxic when produced at high levels (Miki and McHugh, 2004), but the assays are destructive.

\section{Luciferase}

The luciferase (Iuc) reporter gene originates from the firefly Photinus pyralis and encodes the enzyme luciferase (LUC) that catalyzes the ATP-dependent oxidative decarboxylation of luciferin, leading to an excited form of oxyluciferin and to light emission. The flash of light is captured with a luminometer that measures the integrated light output. The total amount of light measured during a given time interval is proportional to the amount of luciferase activity in the sample. Typically, the light flash decays in seconds; enhanced light intensity and a more sustained light reaction were obtained when coenzyme A was added to the reaction, thus improving reactivity and reproducibility of the assay. Initially, the in vivo LUC activity was detected by spraying plant tissues with a luciferin substrate and squeezing it onto a film for exposure (Ow et al., 1986); currently, the faint light from the reporter can be detected with specialized cameras. An advantage of the LUC reporter system is that it permits the nondestructive monitoring of the gene expression patterns, including circadian rhythms, in real time and with great accuracy (Millar et al., 1992; Xu et al., 2010). In addition, the luciferase assay is highly sensitive and results can be obtained within minutes. The limitations of the in vivo applications were overcome by the development of soluble luciferin forms that allow cell penetrance. Thus, LUC has been used to study reporter gene activities in vivo in whole organisms, such as plants, as well as in single cells.

\section{Anthocyanin}

Anthocyanins are endogenous pigments that are responsible for the red, purple, and blue color in flowering plants, form a diverse family of aromatic flavonoid compounds, and play a role in protection against UV, defense response, and attraction of pol- linators and seed dispersers. The biosynthesis of anthocyanins is controlled by a conserved triad of transcriptional regulators (an R2R3-MYB protein, a basic helix-loop-helix [bHLH], and a WD40 repeat protein) of which the overexpression increases the anthocyanin pigment accumulation that has been exploited to monitor both transient and stable gene expression in plants. Overexpression of one or more types of these regulatory genes led to cell-autonomous pigmentation in maize, Arabidopsis, and tobacco (Ludwig et al.,1990; Lloyd et al., 1992; Chu et al., 2013). Anthocyanin accumulation is used as a visual marker in cereal transformation and transgenic seeds (Kawahigashi et al., 2007; Gao et al., 2011). As the anthocyanin reporter is nondestructive, does not require an exogeneous substrate, and is not toxic, there are no related environmental and health concerns.

\section{Promoters for chimeric gene construction}

A promoter refers to the region in the genome sequence upstream of a gene transcription start site that controls the gene expression level and the kind of specificity, i.e. constitutive, inducible, tissue-specific, or developmentally regulated. In transgenic research, promoters are used to drive the expression of the selectable marker to select transformed callus and shoots during the transformation procedure, to follow the T-DNA segregation with the gene of interest in subsequent progenies, and to determine the expression level and specificity of the gene of interest in the progeny. Promoters either originate from heterologous species, which avoids gene silencing, or are cisgenic, which is considered similar to plants bred through conventional breeding methods and, therefore, is more acceptable to consumers.

\section{Constitutive promoters}

Constitutive promoters drive high gene expression levels in all cell types throughout the entire growth and development period and are used to overproduce proteins of interest to study their function in basic research or to generate superior plants or seeds for agronomical purposes. The 35S CaMV gene (Odell et al., 1985) confers a high transgenic expression in most cell types, except in pollen, is independent of environmental conditions, and is well characterized and active in various monocotyledonous and dicotyledonous plants (Benfey and Chua. 1990). The maize Ubi-1 promoter is derived from the constitutively expressed ubiquitin gene (Christensen et al., 1992) and is generally used in cereals (Shrawat and Lörz, 2006). Other strong constitutive promoters with a lot of potential in plant biotechnology have been identified in the rice actin genes OsAct1 and OsAct2 (McElroy et al., 1990), in the Brachypodium distachyon elongation factor and ubiquitin genes $B d E F 1 \alpha$ and $B d U B I 10$ (Coussens et al., 2012; Karimi et al., 2013), and in the switchgrass (Panicum virgatum) ubiquitin genes PvUbi1 and PvUbi2 (Mann et al., 2011).

\section{Organ-, tissue-, domain- or cell type-specific promoters}

Specific promoters are utilized when the transgene expression is preferred at a specific site and/or specific time in development to generate specific phenotypes and avoid adverse effects on plant growth or yield. Several endosperm-specific promoters have been identified that express single or, even, multiple enzymes of biochemical pathways either to dissect the metabolic pathway or to improve the nutritional seed quality (Naqvi et al., 2009; Cous- 
sens et al., 2012). Other promoters have been used for basic or biotechnological research, such as the TA29 tapetum-specific promoter that has been applied successfully for the generation of male sterility in canola (Mariani et al., 1990). The AP1 promoter of the A-type flower gene $A P 1$, which is active in floral whorl one and two- silenced the $A P 3$ gene in whorl two and created a doubled sepaloid flower in Arabidopsis and canola (Byzova et al., 2004) that avoided reflection of the bright-yellow canopy, captured more sun light, and increased yield.

\section{Inducible promoters}

Inducible promoters are specifically activated in response to external stimuli. In contrast to constitutive promoters, the fused transgenes can be expressed at a distinct developmental stage for a certain duration or in a specific tissue. Additionally, the promoters are inactive in the absence of inducers and, therefore, have no negative impact on plant development. The promoter activity can be induced by chemical factors, such as tetracycline, ethanol, steroids, copper ions, and herbicides, or by physical factors, such as heat, cold, and light. Promoters that respond to specific chemical compounds, not found naturally in the organism of interest, are of particular interest in genetic engineering because of the ease of manipulation. Some of the most commonly used chemically inducible promoters in plants (Padidam, 2003) are briefly described. Tetracyclines are particularly attractive as gene expression inducers, because they are small lipophilic compounds that enter easily into eukaryotic cells by passive diffusion and they have been routinely used in both human and veterinary medicine with negligible side effects. The tetracycline-inducible system consists of three main components: the transcriptional repressor, the tetracycline-responsive operator, and an antibiotic of the tetracycline family. The tetracycline-inducible system has been used successfully to produce valuable pharmaceutical or industrial proteins in plant cell suspension cultures (Bortesi et al., 2012). In the steroid-inducible systems, heterelogous proteins are fused to a receptor for glucocorticoid or estrogen and induced by steroids. The glucocorticoid receptor-based steroid-inducible system has significantly advanced the insight into the function of plant transcription factors that control plant developmental pathways (Lloyd et al., 1994; Aoyama et al., 1995). The ethanol-inducible gene expression system is derived from the filamentous fungus Aspergillus nidulans and consists of two elements: the alcoholregulated transcription factor (ALCR) that binds the alcA-derived promoter that regulates the expression of the transgene (Roslan et al., 2001). The ethanol-inducible system has been optimized for the production of proteins in plants (Dugdale et al., 2013).

\section{Databases for plant promoter sequences}

Functional analysis of genes in transgenic plants often demands selection of promoters with appropriate activity patterns. Promoters commonly used in vectors are very limited and provide only little variation in gene expression patterns. Thus far, with an increasing number of sequenced plant genomes, it has become necessary to develop a robust computational method for detecting novel plant promoters. To date, a wide variety of programmes for predicting promoters are available, including PlantPAN (Chang et al., 2008), GRASSIUS (Yilmaz et al., 2008), PlantCARE (Lescot et al., 2002) and TransGene Promoters (TGP) database (Smirnova et al., 2012). However, promoters identified by prediction programs need to be tested by means of reporter genes during plant development and under different stimuli to be applicable in transgenic research.

\section{Vectors for higher plant transformation}

\section{Binary vectors}

A binary vector system (Lee and Gelvin, 2008) consists of two plasmids: the helper plasmid that is constituted of the Agrobacterium Ti plasmid without T-DNA, but carries the vir genes that are necessary for the T-DNA transfer in the plant host genome and acts in trans, and the binary plasmid derived from the commonly used $E$. coli cloning vectors and carrying the gene of interest, flanked by $25 \mathrm{bp}$ terminal repeats, designated the right and left T-DNA border sequences. The binary cloning vector is a standard molecular tool in the Agrobacterium-mediated transformation of higher plants, because it is easy to manipulate in vitro by recombinant DNA methods (Bevan, 1984). Cloning vectors can be assembled to facilitate fusion, overexpression, or downregulation of a variety of genes in plant cells. Their basic skeleton includes a gene of interest under a specific promoter in addition to a selectable and/ or reporter gene. Superbinary vectors have additionally the virB, virG, and virC virulence genes of the supervirulent pTiBo542 plasmid, but require yet another intermediate cloning vector and cointegration step in Agrobacterium, hence complicating the cloning (Komori et al., 2007). A good alternative strategy is the use of the supervirulent Agrobacterium strain EHA101 that contains the supervirulent vir genes of pTiBo542 in the helper plasmid (Hood et al., 1986; Frame et al., 2002; Coussens et al., 2012).

GATEWAY vectors are a set of versatile and robust T-DNA binary vectors that enable quick and easy cloning and transfer of DNA fragments between vector backbones. The utilization of these vectors overcomes the cumbersome conventional cloning procedure, involving DNA restriction and ligation reactions, and the efforts to develop small vectors with unique restriction sites. The GATEWAY cloning technology takes advantage of the site-specific reversible recombination system of phage $\lambda$ that enables rapid and efficient cloning and transfer of DNA fragments related to promoters, cDNA, or gDNA between different expression vectors (Hartley et al., 2000). The DNA fragment is first captured in a GATEWAY donor vector ( $p D O N R)$ through a site-specific recombination reaction resulting in a GATEWAY entry clone ( $p E N T R$ ). Subsequently, the DNA fragment can be recombined into many different GATEWAY destination vectors ( $p D E S T)$, depending on the necessity for overexpression, silencing, and promoter analysis, and results in an expression clone (pEXPR). Several components are essential in the GATEWAY cloning procedure: the att sites, the $c c d B$ gene, and clonase enzymes that recognize the attsite. The GATEWAY att sites are phage-derived recombination sites that facilitate directional cloning and maintain orientations and reading frames of the DNA fragments. The attB sites that flank the DNA of interest recombine with attP sites in a donor vector yielding attL sites in a novel entry clone, a reaction catalyzed by the BP clonase enzyme. Similarly, the attL sites in the entry vector recombine with the attR sites of a destination vector to yield the attB sites in a novel expression clone. Directional cloning is enabled by ensuring that only specific sites recombine, for instance, attB1 with attP1 and not attP2 (Hartley et al., 2000). The BP clonase enzyme is composed of the phage integrase and the $E$. coli integration host factor, whereas the LR 
clonase consists of the phage integrase, the $E$. coli integration host factor, and the phage excisionase. GATEWAY vectors can be selected and maintained by the use of $c c d B$ gene and antibiotic selection markers. The $c c d B$ gene is a negative counterselection marker encoding a protein that interferes with the DNA gyrase, thus inhibiting the $E$. coli growth. $c c d B$ is present in the pDONR or PDEST vectors and is replaced by the DNA of interest upon recombination; hence, $E$. coli cells with the correctly recombined plasmids will survive, whereas cells with unreacted vectors or byproduct-containing $c c d B$ will fail to grow. MultiSite GATEWAY is an extension of the GATEWAY technology, involving additional novel recombination sites with unique specificities to enable the simultaneous cloning of multiple fragments in a single highly efficient and specific in vitro LR clonase reaction. The fragments are cloned in an expression vector in a predefined order, orientation, and translation reading frame (Cheo et al., 2004).

\section{GATEWAY vectors for plant transformation}

GATEWAY destination vectors have been developed to analyze the gene function through Agrobacterium-mediated transformation of dicotyledonous or monocotyledonous plants (Karimi etal., 2007, 2013; Himmelbach et al., 2007). A versatile set of GATEWAYcompatible destination vectors has been constructed to be used in monocotyledonous plants for improvement of transgenic crops either through transgene overexpression or interference RNA (RNAi)-mediated gene suppression (Mann et al., 2012). Unique plant GATEWAY RNAi vectors for the functional analysis of the metabolic pathway in root tissues have been described (Muranaka, 2011). Functional elements built as GATEWAY entry clones, such as promoters, terminators, open reading frames, or diverse tags, can be recombined in a single step in the MultiSite GATEWAY cassettes, thus simplifying design and construction of the recombinant DNA molecules (Karimi et al., 2007). GATEWAY MultiSite entry clones are potentially adaptable to any model system and an inventory of the entry clones and destination vectors for the GATEWAY MultiSite cloning has been established (Petersen and Stowers. 2011). A new series of binary GATEWAY cloning vectors (pAUL1-20) has been generated for C-terminal and $\mathrm{N}$-terminal proteins fused in-frame to four different tags: a single hemagglutinin epitope, a streptavidin-tagll, both epitopes combined to a double tag, and a triple tag consisting of the double tag extended by a Protein A tag possessing a 3C protease cleavage site (Lyska et al., 2013). For multiple gene expression, modified GATEWAY cloning systems have been developed (Chung et al., 2005; Kimura et al., 2013; Vemanna et al., 2013).

\section{Perspectives}

Higher plant transformation technology has become an adaptable platform for cultivar improvement as well as for studying gene functions in plants. Plant DNA can be altered by introducing specific nucleotide substitutions into a gene that change a protein's amino acid sequence, delete genes or chromosomal segments, and insert foreign DNA at precise genomic locations. Such targeted DNA sequence modifications are enabled by sequence-specific nucleases that create double-stranded breaks in the genomic loci. Genomic alterations have recently been achieved through engineered zinc finger nucleases (ZFNs) (Hauschild-Quintern et al., 2012; Tzfira et al., 2012) and transcription activator-like effector nuclease (TALEN) - type transcription factors (Mussolino and Cathomen, 2012). Through an innovative method, designated directed nuclease editor (DNE), selected genes can be incorporated into the plant genome with an enhanced accuracy (http://www.precisionbiosciences.com).

The engineering of a single gene to modify the plant metabolism has appeared promising, but many traits result from many interacting factors that need to be modulated. Such a modulation of complex pathways could be achieved through classical breeding or through the simultaneous engineering of multiple transgenes in nuclear and plastid genomes. It will be interesting to develop versatile molecular toolboxes for the engineering of multiple genes in organelles, such as mitochondria, that hitherto has not been successful. The choice of the preferred technology for multiple transgene engineering will be influenced by many factors, including the T-DNA transfer method, the targeted plant species, the cellular compartmentalization of the pathway of interest, the number of genes to be engineered into the plant, their desired expression levels as well as the available knowledge about metabolite pools, fluxes, and the biochemical regulation of the pathway (Bock, 2013).

Although selectable marker genes are useful tools in the production of transgenic plants by selecting transformed cells from a matrix consisting of mostly untransformed cells, their presence in genetically modified plants and, subsequently, in food, feed, and the environment, are of concern and subject to special governmental regulations in many countries. In addition, they could result in a metabolic burden for the host plants and prevent the reuse of the same selectable markers when a second transformation scheme is needed on the transgenic host. Therefore, innovation in selectable marker removal is necessary to improve existing systems and to develop new technologies. Although the focus of the ZFN and TALEN technologies has been the introduction of local genomic modifications, the ZFN technology has been used for plant selection marker gene deletion. For instance, a preintegrated cassette containing the GUS reporter gene flanked by two ZFN cleavage sites was deleted from a stably transformed plant by crossing it with a second plant expressing a corresponding ZFNgene, a method that can also be applied for selectable marker removal (Petolino et al., 2010). Furthermore, two identical sets of TALEN-binding sequences can be designed to flank a selectable marker in a transformation vector whereby, after expression of TALEN, double-stranded breaks will be induced at both TALEN-binding sequences and remove the selectable marker (Yau and Stewart, 2013).

\section{Acknowledgements}

The authors wish to thank Marc De Block and Geert Angenon for critical reading and suggestions and Martine De Cock for help in preparing the manuscript. E.N. is funded through a VLIR PhD UOS Scholarship. S.A. acknowledges funding of the National Commission for Science, Technology and Innovation (NACOSTI) (research grant NCST/5/003/3rd STICALL/189).

\section{References}

ALONSO JM, STEPANOVAAN, LEISSE TJ, KIM CJ, CHEN H, SHINN P, STEVENSON DK, ZIMMERMAN J, BARAJAS P, CHEUK R, et al. (2003) Genome-wide insertional mutagenesis of Arabidopsis thaliana. Science 301: 653-657 [Err Science 301: 1849]

ANAMI SE, MGUTU AJ, TARACHA C, COUSSENS G, KARIMI M, HILSON P, VAN LIJSEBETTENS M, MACHUKA J (2010) Somatic embryogenesis and plant regeneration of tropical maize genotypes. Plant Cell Tissue Organ Cult 102:285-295.

ATTAR, LAURENS L, BOUCHERON-DUBUISSON E, GUIVARC'HA, CARNERO E GIRAUDAT-PAUTOT V, RECH P, CHRIQUI D (2009) Pluripotency of Arabidopsis 
xylem pericycle underlies shoot regeneration from root and hypocotyl explants grown in vitro. Plant J 57: 626-644.

AOYAMAT, DONG C-H, WU Y, CARABELLI M, SESSA G, RUBERTI I, MORELLI G, CHUAN-H (1995) Ectopic expression of the Arabidopsis transcriptional activator Athb-1 alters leaf cell fate in tobacco. Plant Cell 7: 1773-1785.

BANNO H, IKEDA Y, NIU Q-W, CHUA N-H (2001) Overexpression of Arabidopsis ESR1 induces initiation of shoot regeneration. Plant Cell 13: 2609-2618.

BAOY, DHARMAWARDHANAP, MOCKLERTC, STRAUSSSH (2009) Genome scale transcriptome analysis of shoot organogenesis in Populus. BMC Plant Biol 9: 132.

BENFEY PN, CHUAN-H (1990) The cauliflower mosaic virus 35S promoter: combinatorial regulation of transcription in plants. Science 250: 959-966.

BEVAN M (1984) Binary Agrobacterium vectors for plant transformation. Nucleic Acids Res 12: 8711-8721.

BOCK R (2013) Strategies for metabolic pathway engineering with multiple transgenes. Plant Mol Biol 83: 21-31.

BORKIRD C, CHOIJH, SUNG ZR (1986) Effect of 2,4-dichlorophenoxyacetic acid on the expression of embryogenic program in carrot. Plant Physiol 81: 1143-1146.

BORTESI L, RADEMACHER T, SCHIERMEYER A, SCHUSTER F, PEZZOTTI M, SCHILLBERG S (2012) Development of an optimized tetracycline-inducible expression system to increase the accumulation of interleukin-10 in tobacco BY-2 suspension cells. BMC Biotechnol 12: 40.

BORUC J, VAN DEN DAELE H, HOLLUNDER J, ROMBAUTS S, MYLLE E, HILSON P, INZÉ D, DE VEYLDER L, RUSSINOVA E (2010) Functional modules in the Arabidopsis core cell cycle binary protein-protein interaction network. Plant Cell 22: 1264-1280.

BYZOVA M, VERDUYN C, DE BROUWER D, DE BLOCK M (2004) Transforming petals into sepaloid organs in Arabidopsis and oilseed rape: implementation of the hairpin RNA-mediated gene silencing technology in an organ-specific manner. Planta 218: 379-387.

CHANG AK, DUGGLEBY RG (1998) Herbicide-resistant forms of Arabidopsis thaliana acetohydroxyacid synthase: characterization of the catalytic properties and sensitivity to inhibitors of four defined mutants. Biochem J 333: 765-777.

CHANG W-C, LEE T-Y, HUANG H-D, HUANG H-Y, PAN R-L (2008) PlantPAN: Plant promoter analysis navigator, for identifying combinatorial cis-regulatory elements with distance constraint in plant gene groups. BMC Genomics 9: 561

CHATFIELD SP, CAPRON R, SEVERINO A, PENTTILA P-A, ALFRED S, NAHAL H, PROVART NJ (2013) Incipient stem cell niche conversion in tissue culture: using a systems approach to probe early events in WUSCHEL-dependent conversion of lateral root primordia into shoot meristems. Plant J 73: 798-813.

CHE P, LALL S, HOWELL SH (2007) Developmental steps in acquiring competence for shoot development in Arabidopsis tissue culture. Planta 226: 1183-1194.

CHE P, LALL S, NETTLETON D, HOWELL SH (2006) Gene expression programs during shoot, root, and callus development in Arabidopsis tissue culture. Plant Physiol 141: 620-637.

CHEO DL, TITUS SA, BYRD DRN, HARTLEY JL, TEMPLE GF, BRASCH MA (2004) Concerted assembly and cloning of multiple DNA segments using in vitro sitespecific recombination: functional analysis of multi-segment expression clones. Genome Res 14: 2111-2120.

CHRISTENSEN AH, SHARROCK RA, QUAIL PH (1992) Maize polyubiquitin genes: structure, thermal perturbation of expression and transcript splicing, and promoter activity following transfer to protoplasts by electroporation. Plant Mol. Biol 18: 675-689.

CHRISTIANSON ML, WARNICK DA (1983) Competence and determination in the process of in vitro shoot organogenesis. Dev Biol 95: 288-293.

CHU H, JEONG JC, KIM W-J, CHUNG DM, JEON HK, AHN YO, KIM SH, LEE H-S, KWAKSS, KIM CY (2013). Expression of the sweetpotato R2R3type IbMYB1agene induces anthocyanin accumulation in Arabidopsis. Physiol Plant 148: 189-199.

CHUNG S-M, FRANKMAN EL, TZFIRAT (2005) A versatile vector system for multiple gene expression in plants. Trends Plant Sci 10: 357-361.

CLOUGH SJ, BENT AF (1998) Floral dip: a simplified method for Agrobacteriummediated transformation of Arabidopsis thaliana. Plant J 16: 735-743.

COUSSENS G, AESAERT S, VERELST W, DEMEULENAERE M, DE BUCK S, NJUGUNAE, INZÉ D, VAN LIJSEBETTENS M (2012) Brachypodium distachyon promoters as efficient building blocks for transgenic research in maize. J Exp Bot 63: 4263-4273.
DATTA SK, PETERHANS A, DATTA K, POTRYKUS I (1990) Genetically engineered fertile indica-rice recovered from protoplasts. Biotechnology 8: 736-740.

DE BLOCK M, BOTTERMAN J, VANDEWIELE M, DOCKX J, THOEN C, GOSSELÉ V, MOVVA R, THOMPSON C, VAN MONTAGU M, LEEMANS J (1987) Engineering herbicide resistance in plants by expression of a detoxifying enzyme. EMBO J 6: 2513-2518.

DE BLOCK M, DE SONVILLE A, DE BROUWER D (1995) The selection mechanism of phosphinothricin is influenced by the metabolic status of the tissue. Planta 197: 619-626.

DE BLOCK M, HERRERA-ESTRELLA L, VAN MONTAGU M, SCHELL J (1984) Expression of foreign genes in regenerated plants and their progeny. EMBO J 3: $1681-1689$.

DE CLEENE M, DE LEY J (1976) The host range of crown gall. Bot Rev 42: 389-466.

DUCLERCQ J, SANGWAN-NORREEL B, CATTEROU M, SANGWAN RS (2011) De novo shoot organogenesis: from art to science. Trends Plant Sci 16: 597-606.

DUGDALE B, MORTIMER CL, KATO M, JAMES TA, HARDING RM, DALE JL (2013) In plant activation: an inducible, hyperexpression platform for recombinant protein production in plants. Plant Cell 25: 2429-2443.

ELHITI M, STASOLLAC (2012) In vitro shoot organogenesis and hormone response are affected by the altered levels of Brassica napus meristem genes. Plant Sci 190: 40-51.

FRALEY RT, ROGERS SG, HORSCH RB, SANDERS PR, FLICK JS, ADAMS SP, BITTNER ML, BRAND LA, FINK CL, FRY JS, GALLUPPI GR, GOLDBERG SB, HOFFMANN NL, WOO SC (1983) Expression of bacterial genes in plant cells. Proc Natl Acad Sci USA 80: 4803-4807.

FRAME BR, SHOU H, CHIKWAMBA RK, ZHANG Z, XIANG C, FONGER TM, PEGG SEK, LI B, NETTLETON DS, PEI D, WANG K (2002) Agrobacterium tumefaciens-mediated transformation of maize embryos using a standard binary vector system. Plant Physiol 129: 13-22.

FROMM ME, MORRISH F, ARMSTRONG C, WILLIAMS R, THOMAS J, KLEIN TM (1990) Inheritance and expression of chimeric genes in the progeny of transgenic maize plants. Biotechnology 8: 833-839.

GAO X, ZHANG L, ZHOU S, WANG C, DENG X, ZHANG H, YANG G, JAVEED H, HE G (2011). AtMYB12 gene: a novel visible marker for wheat transformation. Mol Biol Rep 38: 183-190.

GELVIN SB (2012) Traversing the Cell: Agrobacterium T-DNA's journey to the host genome. Front Plant Sci 3: 52.

GHEYSEN G, VILLARROELR, VAN MONTAGU M (1991) Illegitimate recombination in plants: a model for T-DNA integration. Genes Dev 5: 287-297.

GOLDSWORTHYA, STREET HE (1965) The carbohydrate nutrition of tomato roots. VIII. The mechanism of the inhibition by D-mannose of the respiration of excised roots. Ann Bot 29: 45-58.

HARTLEY JL, TEMPLE GF, BRASCH MA (2000) DNA cloning in vitro using sitespecific recombination. Genome Res 10: 1788-1795.

HASELOFFJ, SIEMERING KR, PRASHERDC, HODGE S (1997) Removal of a cryptic intron and subcellular localization of green fluorescent protein are required to mark transgenic Arabidopsis plants brightly. Proc Natl Acad Sci USA 94: 2122-2127.

HAUSCHILD-QUINTERN J, PETERSEN B, COST GJ, NIEMANN H (2013) Gene knockout and knockin by zinc-finger nucleases: current status and perspectives. Cell Mol Life Sci 70: 2969-2983.

HERRERA-ESTRELLA L, DE BLOCK M, MESSENS E, HERNALSTEENS J-P, VAN MONTAGU M, SCHELL J (1983) Chimeric genes as dominant selectable markers in plant cells. EMBO J 2: 987-995.

HIMMELBACH A, ZIEROLF U, HENSEL G, RIECHEN J, DOUCHKOV D, SCHWEIZER P, KUMLEHN J (2007) A set of modular binary vectors for transformation of cereals. Plant Physiol 145: 1192-1200.

HOOD EE, HELMER GL, FRALEY RT, CHILTON M-D (1986) The hypervirulence of Agrobacterium tumefaciens A281 is encoded in a region of pTiBo542 outside of T-DNA. J Bacteriol 168: 1291-1301.

HORSCH RB, FRALEY RT, ROGERS SG, SANDERS PR, LLOYD A, HOFFMANN $N$ (1984) Inheritance of functional foreign genes in plants. Science 223: 496-498.

JEFFERSON RA, KAVANAGH TA, BEVAN MW (1987) GUS fusions: $\beta$-glucuronidase as a sensitive and versatile gene fusion marker in higher plants. EMBO $\mathrm{J}$ : 3901-3907.

JIANG C, MITHANI A, GAN X, BELFIELD EJ, KLINGLER JP, ZHU J-K, RAGOUS- 
SIS J, MOTT R, HARBERD NP (2011) Regenerant Arabidopsis lineages display a distinct genome-wide spectrum of mutations conferring variant phenotypes. Current Biol 21:1385-1390.

JOERSBO M, DONALDSON I, KREIBERG J, PETERSEN SG, BRUNSTEDT J, OKKELS FT (1998) Analysis of mannose selection used for transformation of sugar beet. $\mathrm{Mol}$ Breed 4: 111-117.

KARIMI M, DEPICKER A, HILSON P (2007) Recombinational cloning with plant Gateway vectors. Plant Physiol 145: 1144-1154.

KARIMI M, INZÉ D, VAN LIJSEBETTENS M, HILSON P (2013) Gateway vectors for transformation of cereals. Trends Plant Sci 18: 1-4.

KAWAHIGASHI H, HIROSE S, IWAI T, OHASHI Y, SAKAMOTO W, MAEKAWA $\mathrm{M}$, OHKAWA Y (2007). Chemically induced expression of rice OSB2 under the control of the OsPR1.1 promoter confers increased anthocyanin accumulation in transgenic rice. J Agric Food Chem 55: 1241-1247.

KIKUCHI A, SANUKI N, HIGASHI K, KOSHIBA T, KAMADA H (2006) Abscisic acid and stress treatment are essential for the acquisition of embryogenic competence by carrot somatic cells. Planta 223: 637-645.

KIMURA T, NAKAO A, MURATA S, KOBAYASHI Y, TANAKA Y, SHIBAHARA K, KAWAZU T, NAKAGAWAT (2013) Development of the Gateway recycling cloning system for multiple linking of expression cassettes in a defined order, and direction on Gateway compatible binary vectors. Biosci Biotechnol Biochem 77: 430-434.

KIRIENKO DR, LUO A, SYLVESTER AW (2012) Reliable transient transformation of intact maize leaf cells for functional genomics and experimental study. Plant Physiol 159: 1309-1318.

KLEIN TM, FROMM M, WEISSINGER A, TOMES D, SCHAAF S, SLETTEN M, SANFORD JC (1988a) Transfer of foreign genes into intact maize cells with high-velocity microprojectiles. Proc Natl Acad Sci USA 85: 4305-4309.

KOMORI T, IMAYAMA T, KATO N, ISHIDA Y, UEKI J, KOMARI T (2007) Current status of binary vectors and superbinary vectors. Plant Physiol 145: 1155-1160.

KOORNNEEF M, BADE J, HANHART C, HORSMAN K, SCHEL J, SOPPE W, VERKERK R, ZABEL P (1993) Characterization and mapping of a gene controlling shoot regeneration in tomato. Plant J 3: 131-141.

KRAMER C, DiMAIO J, CARSWELL GK, SHILLITO RD (1993) Selection of transformed protoplast-derived Zea mays colonies with phosphinothricin and a novel assay using the $\mathrm{pH}$ indicator chlorophenol red. Planta 190: 454-458.

LEE L-Y, GELVIN SB (2008) T-DNA binary vectors and systems. Plant Physiol 146: 325-332.

LESCOTM, DÉHAISP, THIJS G, MARCHALK, MOREAUY, VAN de PEER Y, ROUZÉ $P$, ROMBAUTS S (2002) PlantCARE, a database of plant cis-acting regulatory elements and a portal to tools for in silico analysis of promoter sequences. Nucleic Acids Res 30: 325-327.

LLOYD AM, WALBOT V, DAVIS RW (1992). Arabidopsis and Nicotiana anthocyanin production activated by maize regulators $R$ and $C 1$. Science 258: 1773-1775.

LLOYD AM, SCHENA M, WALBOT V, DAVIS RW (1994) Epidermal cell fate determination in Arabidopsis: patterns defined by a steroid-inducible regulator. Science 266: 436-439.

LOTAN T, OHTO MA, YEE KM, WEST MAL, LO R, KWONG RW, YAMAGISHI K, FISCHER RL, GOLDBERG RB, HARADA JJ (1998) Arabidopsis LEAFY COTYLEDON1 is sufficient to induce embryo development in vegetative cells. Cell 93: 1195-1205.

LUDWIG SR, BOWEN B, BEACH L, WESSLER SR (1990). A regulatory gene as a novel visible marker for maize transformation. Science 247: 449-450.

LYSKAD, ENGELMANN K, MEIERHOFF K, WESTHOFFP (2013) pAUL:AGatewaybased vector system for adaptive expression and flexible tagging of proteins in Arabidopsis. PLoS ONE 8: e53787.

MANN DGJ, KING ZR, LIU W, JOYCE BL, PERCIFIELD RJ, HAWKINS JS, LAFAYETTE PR, ARTELT BJ, BURRIS JN, MAZAREI M, BENNETZEN JL, PARROTT WA, STEWART CN. Jr. (2011) Switchgrass (Panicum virgatum L.) polyubiquitin gene (PvUbi1 and $P v U b i 2)$ promoters for use in plant transformation. BMC Biotechnol 11: 74.

MANN DGJ, LAFAYETTE PR, ABERCROMBIE LL, KING ZR, MAZAREI M, HALTER MC, POOVAIAHCR, BAXTER H, SHEN H, DIXONRA, PARROTTWA, STEWART CN. Jr. (2012) Gateway-compatible vectors for high-throughput gene functional analysis in switchgrass (Panicum virgatum L.) and other monocot species. Plant Biotechnol J 10: 226-236.

MARIANI C, DE BEUCKELEER M, TRUETTNER J, LEEMANS J, GOLDBERG RB
(1990) Induction of male sterility in plants by a chimaeric ribonuclease gene. Nature 347: 737-741.

McELROY D, ZHANG W, CAO J, WU R (1990) Isolation of an efficient actin promoter for use in rice transformation. Plant Cell 2: 163-171.

MIKI B, McHUGH S (2004) Selectable marker genes in transgenic plants: applications, alternatives and biosafety. J Biotechnol 107: 193-232.

MILLAR AJ, SHORT SR, HIRATSUKA K, CHUA N-H, KAY SA (1992) Firefly luciferase as a reporter of regulated gene expression in higher plants. Plant $\mathrm{Mol} \mathrm{Biol}$ Rep 10: 324-337.

MURAKAMI T, ANZAI H, IMAI S, SATOH A, NAGAOKA K, THOMPSON CJ (1986) The bialaphos biosynthetic genes of Streptomyces hygroscopicus: molecular cloning and characterization of the gene cluster. Mol Gen Genet 205: 42-50.

MURANAKAT (2011) Plant Gateway vectors for RNAi as a tool for functional genomic studies. Methods Mol Biol 744: 27-35.

MUSSOLINO C, CATHOMEN T (2012) TALE nucleases: tailored genome engineering made easy. Curr Opin Biotechnol 23: 644-650.

NAGEL RJ, MANNERS JM, BIRCH RG (1992) Evaluation of an ELISA assay for rapid detection and quantification of neomycin phosphotransferase II in transgenic plants. Plant Mol Biol Rep 10: 263-272.

NAGY JI, MALIGAP (1976) Callus induction and plant regeneration from mesophyl protoplasts of Nicotiana sylvestris. Z Pflanzenphysiol 78: 453-455.

NAQVI S, ZHU C, FARRE G, RAMESSAR K, BASSIE L, BREITENBACH J, PEREZ CONESA D, ROS G, SANDMANN G, CAPELL T, CHRISTOU P (2009) Transgenic multivitamin corn through biofortification of endosperm with three vitamins representing three distinct metabolic pathways. Proc Natl Acad $\mathrm{Scl}$ USA 106: 7762-7767.

NIEDZ RP, SUSSMAN MR, SATTERLEE JS (1995) Green fluorescent protein: an in vivo reporter of plant gene expression. Plant Cell Rep 14: 403-406.

O'KENNEDY MM, STARK HC, DUBE N (2011) Biolistic-mediated transformation protocols for maize and pearl millet using pre-cultured immature zygotic embryos and embryogenic tissue. Methods Mol Biol 710: 343-354.

ODELL JT, NAGY F, CHUA N-H (1985) Identification of DNA sequences required for activity of the cauliflower mosaic virus 35S promoter. Nature 313: 810-812.

OLSZEWSKI NE, MARTIN FB, AUSUBEL FM (1988) Specialized binary vector for plant transformation: expression of the Arabidopsis thaliana AHAS gene in Nicotiana tabacum. Nucleic Acids Res 16: 10765-10782.

OW DW, WOOD KV, DeLUCA M, de WET JR, HELINSKI DR, HOWELL SH (1986) Transient and stable expression of the firefly luciferase gene in plant cells and transgenic plants. Science 234: 856-859.

PADIDAM M (2003) Chemically regulated gene expression in plants. Curr Opin Plant Biol 6: 169-177.

PARCY F, VALON C, RAYNAL M, GAUBIER-COMELLA P, DELSENY M, GIRAUDAT J (1994) Regulation of gene expression programs during Arabidopsis seed development: roles of the $A B / 3$ locus and of endogenous abscisic acid. Plant Cell 6: 1567-1582.

PETERSEN LK, STOWERS RS (2011) A Gateway multisite recombination cloning toolkit. PLOS ONE 6: e24531.

PETOLINO JF, WORDEN A, CURLEE K, CONNELL J, STRANGE MOYNAHAN TL, LARSEN C, RUSSELL S (2010) Zinc finger nuclease-mediated transgene deletion. Plant Mol Biol 73: 617-628.

PRAKASH AP, KUMAR PP (2002) PKMADS1 is a novel MADS box gene regulating adventitious shoot induction and vegetative shoot development in Paulownia kawakamii. Plant J 29: 141-151.

PRASHER DC, ECKENRODE VK, WARD WW, PRENDERGAST FG, CORMIER MJ (1992) Primary structure of the Aequorea victoria green-fluorescent protein Gene 111: 229-233.

REED J, PRIVALLE L, POWELL ML, MEGHJI M, DAWSON J, DUNDER E, SUTTIE J, WENCK A, LAUNIS K, KRAMER C, CHANG Y-F, HANSEN G, WRIGHT $M$ (2001) Phosphomannose isomerase: an efficient selectable marker for plant transformation. In Vitro Cell Dev Biol-Plant 37: 127-132.

REISS B, SPRENGEL R, WILL H, SCHALLER H (1984) A new sensitive method for qualitative and quantitative assay of neomycin phosphotransferase in crude cell extracts. Gene 30: 211-218.

ROSELLINI D (2011) Selectable marker genes from plants: reliability and potential. In Vitro Cell Dev Biol-Plant 47: 222-233. 
ROSLAN HA, SALTER MG, WOOD CD, WHITE MRH, CROFT KP, ROBSON F, COUPLAND G, DOONAN J, LAUFS P, TOMSETT AB, CADDICK MX (2001) Characterization of the ethanol-inducible alc gene-expression system in Arabidopsis thaliana. Plant $\mathrm{J}$ 28: 225-235.

SCHMIDT EDL, GUZZO F, TOONEN MAJ, de VRIES S (1997) A leucine-rich repeat containing receptor-like kinase marks somatic plant cells competent to form embryos. Development 124: 2049-2062.

SEOM-S, JINM, LEES-S, KWONS-J, MUNJ-H, PARKB-S, VISSERRGF, BONNEMA G, SOHN S-H (2013) Mapping quantitative trait loci for tissue culture response in VCS3M-DH population of Brassica rapa. Plant Cell Rep $32:$ 1251-1261.

SHEEN J (2001) Signal transduction in maize and Arabidopsis mesophyll protoplasts. Plant Physiol 127: 1466-1475.

SHIMOMURA O, JOHNSON FH, SAIGA Y (1962) Extraction, purification and properties of aequorin, a bioluminescent protein from the luminous hydromedusan, Aequorea. J Cell Comp Physiol 59: 223-239.

SHOU H, FRAME BR, WHITHAM SA, WANG K (2004) Assessment of transgenic maize events produced by particle bombardment or Agrobacterium-mediated transformation. Mol Breed 13: 201-208.

SHRAWAT AK, LÖRZ H (2006) Agrobacterium-mediated transformation of cereals: a promising approach crossing barriers. Plant Biotechnol J 4: 575-603.

SKOOG F, MILLER CO (1957) Chemical regulation of growth and organ formation in plant tissues cultures in vitro. Symp Soc Exp Biol 11: 118-131.

SMIRNOVAOG, IBRAGIMOVASS, KOCHETOV AV (2012) Simple database to select promoters for plant transgenesis. Transgenic Res 21: 429-437.

STEWARD FC, MAPES MO, MEARS K (1958) Growth and organized development of cultured cells. II. Organization in cultures grown from freely suspended cells. Am J Bot 45: 705-708.

SUGIMOTO K, GORDON SP, MEYEROWITZ EM (2011) Regeneration in plants and animals: dedifferentiation, transdifferentiation, or just differentiation? Trends Cell Biol 21: 212-218.

SUGIMOTO K, JIAO Y, MEYEROWITZ EM (2010) Arabidopsis regeneration from multiple tissues occurs via a root development pathway. Dev Cell 18: 463-471.

SUGIYAMA M (1999) Organogenesis in vitro. Curr Opin Plant Biol 2: 61-64.

THOMPSONCJ, RAO MOVVA N, TIZARD R, CRAMERI R, DAVIES JE, LAUWEREYS M, BOTTERMAN J (1987) Characterization of the herbicide-resistance gene bar from Streptomyces hygroscopicus. EMBO J 6: 2519-2523.

TORELLI A, BORINATO M, SORAGNI E, BOLPAGNI R, BOTTURA C, BRANCA C (2004) The delay in hormonal treatment modulates the expression of LESK1, a gene encoding a putative serine-threonine kinase, marker of in vitro caulogenesis in tomato (Lycopersicon esculentum Mill.). Plant Sci 167: 607-620.

TRUJILLO-MOYA C, GISBERT C (2012) The influence of ethylene and ethylene modulators on shoot organogenesis in tomato. Plant Cell Tissue Organ Cult 111: 41-48.

TZFIRA T, CITOVSKY V (2006) Agrobacterium-mediated genetic transformation of plants: biology and biotechnology. Curr Opin Biotechnol 17: 147-154.

TZFIRA T, WEINTHAL D, MARTON I, ZEEVI V, ZUKER A, VAINSTEIN A (2012) Genome modifications in plant cells by custom-made restriction enzymes. Plant Biotechnol J 10: 373-389.

VALVEKENS D, VAN MONTAGU M, VAN LIJSEBETTENS M (1988) Agrobacterium tumefaciens-mediated transformation of Arabidopsis thaliana root explants by using kanamycin selection. Proc Natl Acad Sci USA 85: 5536-5540.

van den ELZEN PJM, TOWNSEND J, LEE KY, BEDBROOK JR (1985) A chimaeric hygromycin resistance gene as a selectable marker in plant cells. Plant Mol Biol 5: 299-302.

VAN LIJSEBETTENS M, VANDERHAEGHEN R, VAN MONTAGU M (1991) Insertional mutagenesis in Arabidopsis thaliana: isolation of a T-DNA-linked mutation that alters leaf morphology. Theor Appl Genet 81: 277-284.

VEMANNA RS, CHANDRASHEKAR BK, HANUMANTHA RAO HM, SATHYANARAYANAGUPTA SK, SARANGI KS, NATARAJA KN, UDAYAKUMAR M (2013) A modified MultiSite Gateway cloning strategy for consolidation of genes in plants. Mol Biotechnol 53: 129-138.

VOSS, U., LARRIEU, A and WELLS, D.M. (2013). From jellyfish to biosensors: the use of fluorescent proteins in plants. Int. J. Dev. Biol. 57: 525-533. [DOI: $10.1387 /$ ijdb.130208dw]

WALDRON C, MURPHY EB, ROBERTS JL, GUSTAFSON GD, ARMOUR SL, MALCOLM SK (1985) Resistance to hygromycin B: a new marker for plant transformation studies. Plant Mol Biol 5: 103-108.

WOHLLEBEN W, ARNOLD W, BROER I, HILLEMANN D, STRAUCH E, PÜHLER A (1988) Nucleotide sequence of the phosphinothricin $\mathrm{N}$-acetyltransferase gene from Streptomyces viridochromogenes Tü494 and its expression in Nicotiana tabacum. Gene 70: 25-37.

XU X, XIE Q, McCLUNG CR (2010) Robust circadian rhythms of gene expression in Brassica rapa tissue culture. Plant Physiol 153: 841-850.

YANG M, BARANOV E, MOOSSA AR, PENMAN S, HOFFMAN RM (2000) Visualizing gene expression by whole-body fluorescence imaging. Proc Natl Acad Sci USA 97: 12278-12282.

YANG T-T, CHENG L, KAIN SR (1996) Optimized codon usage and chromophore mutations provide enhanced sensitivity with the green fluorescent protein. Nucleic Acids Res 24: 4592-4593.

YAOJ-L, TOMES S, GLEAVEAP (2013) Transformation of apple (Malus $x$ domestica) using mutants of apple acetolactate synthase as a selectable marker and analysis of the T-DNA integration sites. Plant Cell Rep 32: 703-714.

YAU Y-Y, STEWART CN Jr (2013) Less is more: strategies to remove marker genes from transgenic plants. BMC Biotechnol 13: 36.

YILMAZ A, NISHIYAMA MY Jr, GARCIA FUENTES B, MENDES SOUZA G, JANIES D, GRAY J, GROTEWOLD E (2009) GRASSIUS: a platform for comparative regulatory genomics across the grasses. Plant Physiol 149: 171-180.

ZIMMERMAN JL (1993) Somatic embryogenesis: a model for early development in higher plants. Plant Cell 5: 1411-1423. 


\section{Further Related Reading, published previously in the Int. J. Dev. Biol.}

Reproductive Meristem22 is a unique marker for the early stages of stamen development Elisson Romanel, Pradeep Das, Richard M. Amasino, Jan Traas, Elliot Meyerowitz and Marcio Alves-Ferreira Int. J. Dev. Biol. (2011) 55: 657-664

http://dx.doi.org/10.1387/ijdb.113340er

Multi-probe in situ hybridization to whole mount Arabidopsis seedlings

Leonardo Bruno, Antonella Muto, Natasha D. Spadafora, Domenico laria, Adriana Chiappetta, Mieke Van Lijsebettens and Maria B. Bitonti

Int. J. Dev. Biol. (2011) 55: 197-203

http://dx.doi.org/10.1387/ijdb.103132lb

Common themes in siRNA-mediated epigenetic silencing pathways André Verdel, Aurélia Vavasseur, Madalen Le Gorrec and Leila Touat-Todeschini Int. J. Dev. Biol. (2009) 53: 245-257

http://dx.doi.org/10.1387/ijdb.082691av

Plant Developmental Biology in Spain: from the origins to our days and prospects for the future

José-Pío Beltrán

Int. J. Dev. Biol. (2009) 53: 1219-1234

http://dx.doi.org/10.1387/ijdb.072456jb

Historical perspectives on plant developmental biology

Mieke Van Lijsebettens and Marc Van Montagu

Int. J. Dev. Biol. (2005) 49: 453-465

http://dx.doi.org/10.1387/ijdb.041927ml

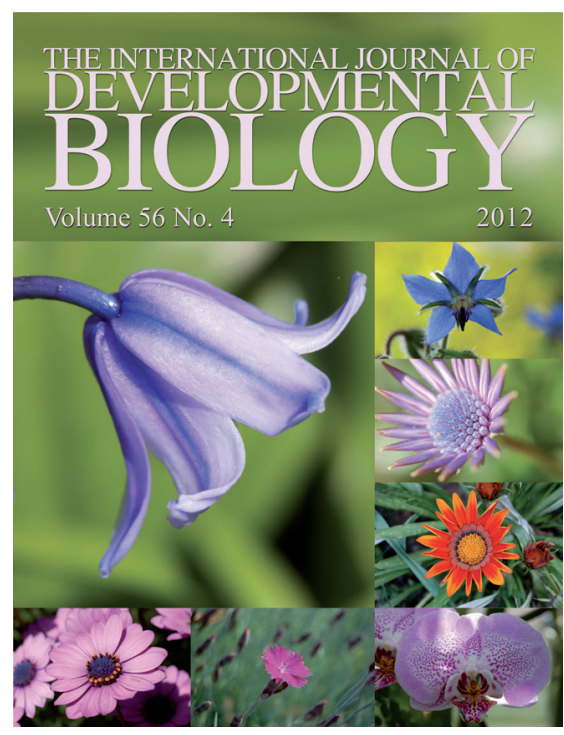

5 yr ISI Impact Factor $(2011)=2.959$

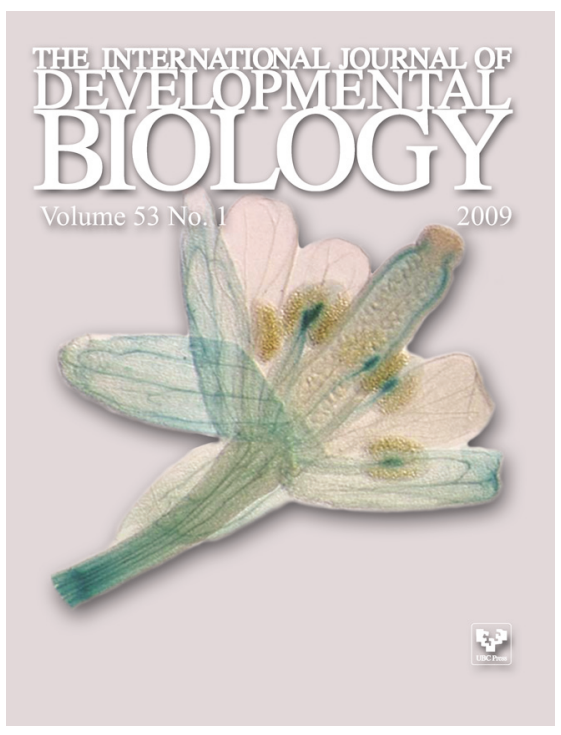

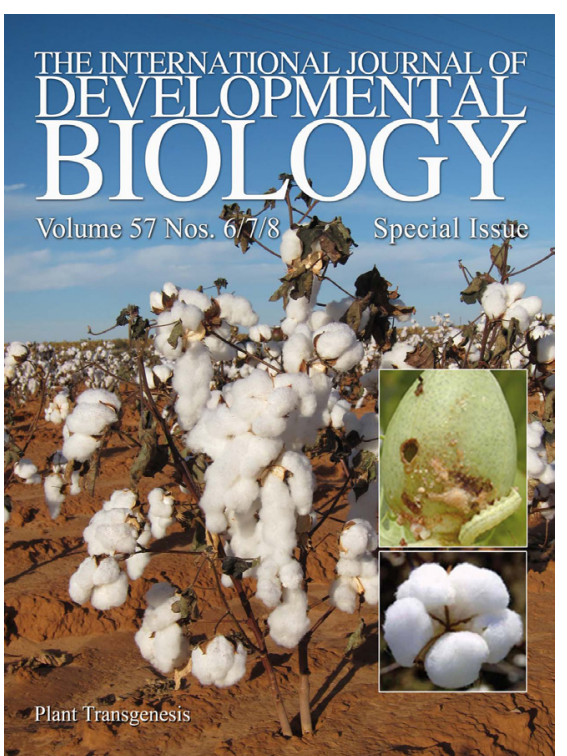

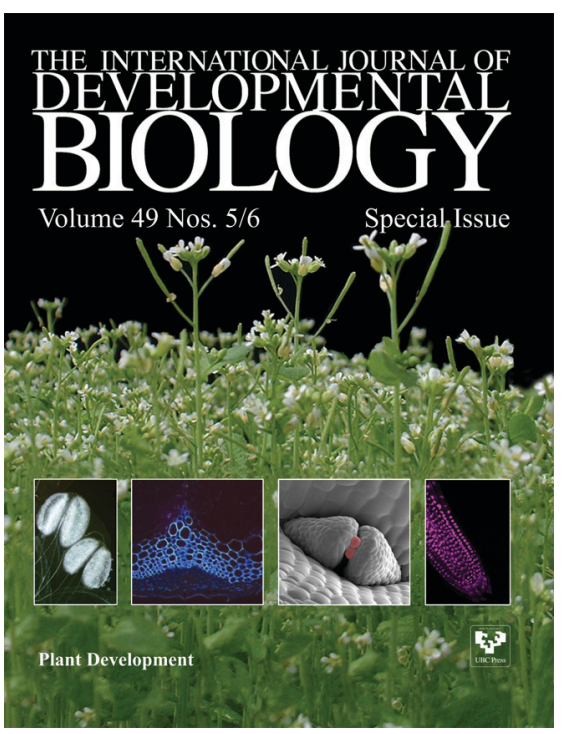

